\title{
Advanced fabrication of lightweight aerogels from fly ash for thermal insulation
}

\author{
Nga Hoang Nguyen Do ${ }^{1,2}$, Huy Gia Tran ${ }^{1,2}$, Huong Ly Xuan Doan ${ }^{1,2}$, Nghiep Quoc Pham $^{3}$, Kien Anh Le ${ }^{3}$, \\ Phung Kim Le ${ }^{1,2, *}$
}

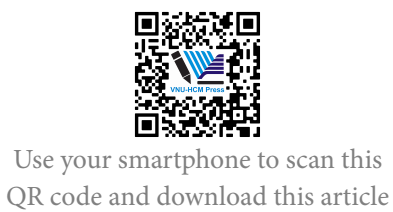

${ }^{1}$ Faculty of Chemical Engineering, Ho Chi Minh City University of Technology (HCMUT), 268 Ly Thuong Kiet Street, District 10, Ho Chi Minh City, Vietnam

${ }^{2}$ Vietnam National University Ho Chi Minh City, Linh Trung Ward, Thu Duc District, Ho Chi Minh City, Vietnam

${ }^{3}$ Institute for Tropicalization and Environment, 57A Truong Quoc Dung Street, Phu Nhuan District, Ho Chi Minh City, Vietnam

\section{Correspondence}

Phung Kim Le, Faculty of Chemical Engineering, Ho Chi Minh City University of Technology (HCMUT), 268 Ly Thuong Kiet Street, District 10, Ho Chi Minh City, Vietnam

Vietnam National University Ho Chi Minh City, Linh Trung Ward, Thu Duc District, Ho Chi Minh City, Vietnam

Email: phungle@hcmut.edu.vn

History

- Received: 29-10-2020

- Accepted: 28-12-2020

- Published: 13-02-2021

DOI : 10.32508/stdjet.v3i4.786

\section{Check for updates}

Copyright

$\odot$ VNU-HCM Press. This is an openaccess article distributed under the terms of the Creative Commons Attribution 4.0 International license.

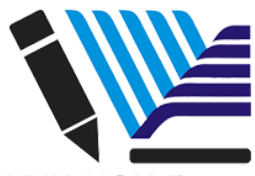

VNU-HCM Press

\begin{abstract}
For the first time, an environmentally friendly and effective procedure to produce high-value engineering aerogels from fly ash (FA) has been developed by dispersing FA particles into a mixture of biodegradable polyvinyl alcohol (PVA) and carboxymethyl cellulose (CMC), followed by freezedrying. The effect of FA content on the physical properties, morphology, mechanical strength, and thermal conductivity of FA aerogels is also studied comprehensively. The lightweight FA aerogels show a low density of $0.072-0.093 \mathrm{~g} / \mathrm{cm}^{3}$ with high porosity of $94.94-95.78 \%$. The morphology of aerogels shows the uniform distribution of FA particles in PVA-CMC matrixes that creates a porous structure with a pore size of 2-5 $\mu \mathrm{m}$. Therefore, the FA aerogels exhibit good heat insulation with extremely low thermal conductivity of $0.040-0.047 \mathrm{~W} / \mathrm{m} . \mathrm{K}$ at ambient temperature and pressure that is comparable to some commercial insulation materials such as mineral wool, fiberglass, expanded polystyrene, and other silica-based aerogels from waste. Moreover, the compressive modulus of FA aerogels is about $67.73-254.75 \mathrm{kPa}$ indicating their excellent mechanical properties under $1 \mathrm{kN}$ vertical compression. The experimental results indicate the significant better durability of FA aerogels than that of previous aerogels from other wastes such as sugarcane bagasse (88 kPa), pineapple leaf fibers $(1.64-5.34 \mathrm{kPa})$, recycled polyethylene terephthalate $(1.16$ $2.87 \mathrm{kPa})$, spent coffee grounds $(5.41-15.62 \mathrm{kPa})$, and silica - cellulose $(86-169 \mathrm{kPa})$. It is concluded that FA aerogels are a promising candidate as a lightweight thermal insulating material.
\end{abstract}

Key words: Fly Ash, Aerogel, Thermal Insulation, Morphology, Mechanical Strength

\section{INTRODUCTION}

Fly ash particles, generated during burning coal in thermal power plants, are one of the reasons causing severe impacts on our ecological environment. Only about $30 \%$ of the total FA in Vietnam is recycled into useful products such as concrete, bricks, and insulation panels ${ }^{1}$. The remaining FA is piled-up or stored in reservoirs. The surrounding soil, groundwater, and surface water nearby can be contaminated via the percolation of hazardous heavy metals leached from FA. The FA particles can even cause siltation and clog the natural drainage system when they reach to the subsoil $^{2}$. At the same time, FA particles, which are generally spherical with the size between 10 to $100 \mu \mathrm{m}$, are released into the air and become a major source of gas pollution surrounding the dumping sites ${ }^{3}$.

In recent years, efforts to recycle FA into high-value engineering materials have been carried out to address the pollution of FA and increase the value of this industrial by-product. Among the advanced materials, aerogel is of interest to many scientists due to its extraordinary characteristics such as extremely low density $\left(0.07-0.15 \mathrm{~g} / \mathrm{cm}^{3}\right)$, high porosity $(90-99 \%)$, varied surface area $\left(13.8-600 \mathrm{~m}^{2} / \mathrm{g}\right)$, flexible mechanical properties $(0.95-150 \mathrm{MPa})$, and an exceptionally low thermal conductivity which can be down to $0.018 \mathrm{~W} / \mathrm{m} \cdot \mathrm{K}^{4}$. Since the first commercial production, aerogels have been used in many fields, such as aerospace, catalysis, electrical engineering, to name a few $^{5}$.

FA has been used as raw material for synthesizing $\mathrm{SiO}_{2}-\mathrm{Al}_{2} \mathrm{O}_{3}$ aerogels thanks to its composition including rich $\mathrm{SiO}_{2}(58.9 \%)$ and $\mathrm{Al}_{2} \mathrm{O}_{3}(23.9 \%)^{6}$. In 2010, Shi et al. fabricated silica aerogels from the industrial FA by ambient pressure drying. The process includes two stages, preparation of silicate solution from FA by hydrothermal reaction with alkali solvent, and fabrication of porous silica aerogels from the obtained solution by sol-gel method. However, before drying, the wet gel was modified by solvent exchange with hydrophobic trimethylchlorosilane (TMCS)/ethanol/hexane solution. The resulting aerogels are lightweight and hydrophobic with a large surface area of $362.2-907.9 \mathrm{~m}^{2} / \mathrm{g}^{7}$. A highly porous silica aerogel could be fabricated by a combination of FA and trona ore which is mainly composed of 
$\mathrm{Na}_{2} \mathrm{CO}_{3}$ and the ambient pressure drying method ${ }^{1}$. To minimize drying shrinkage, the gel obtained after gelation of silicate solution with acid is coagulated with ethanol to form alcogel, after which the alcogel is modified with hydrophobic TMCS/ethanol/hexane solution. The developed aerogel exhibited hydrophobicity and a large specific surface area of $856.2 \mathrm{~m}^{2} / \mathrm{g}$. Overall, to synthesize aerogels from FA, the ash is firstly treated with strong alkali to recover silica in the form of silicate solution, followed by a sol-gel route, solvent exchange with hydrophobic solvent, and ambient pressure drying to produce porous aerogels ${ }^{1,7}$. The synthesis process goes through many steps with prolonged time due to gelation, coagulation, and surface modification happening at room temperature from 12 to 24 hours for each step. With an approach to sustainable development by using less toxic chemicals, shortening synthesis time and applicability in mass production, in this study, FA is dispersed into a viscous solution containing inexpensive and biodegradable polyvinyl alcohol and carboxymethyl cellulose to form a homogenous and stable mixture, followed by gelation at a low temperature of $-50{ }^{\circ} \mathrm{C}$ before sublimation to remove water under vacuum condition. To the best of our knowledge, no studies have been conducted on the synthesis of FA aerogels by this technique. The FA aerogels generated are comprehensively investigated in terms of their physical properties such as density, porosity, morphology, and potential application in thermal insulation.

\section{MATERIALS AND METHODS}

\section{Materials}

FA is collected from Duyen Hai Thermal Power Company and separated by a cyclonic system to obtain uniform FA particles. The size of FA before and after separation is 5.71 and $1.37 \mu \mathrm{m}$, respectively. The particle distribution and morphology of FA are shown in Figure 1. The chemical composition of FA before and after separation is also tabulated in Table 1. The first binder polyvinyl alcohol (PVA) is purchased from $\mathrm{Ku}$ raray Asia Pacific Pte. Ltd (Singapore) with a density $\rho_{P V A}$ of $1.19 \mathrm{~g} / \mathrm{cm}^{3}$ and the viscosity of $4.0 \mathrm{wt}$.\% aqueous PVA solution is $22.7 \mathrm{cPs}$. The second binder carboxymethyl cellulose (CMC) is purchased from Nippon Paper Industries Co., Ltd (Japan) with a density $\rho_{C M C}$ of $1.59 \mathrm{~g} / \mathrm{cm}^{3}$. All solution is prepared in distilled water (DW).

\section{Fabrication of FA aerogels}

Initially, the mixture of PVA and CMC solution with a solute mass ratio of 2:0.5 is prepared in DW which is heated to $80^{\circ} \mathrm{C}$. Then, FA with determined weight is dispersed into the PVA/CMC solution by agitating for 3 hours at $80{ }^{\circ} \mathrm{C}$ to form a homogenous mixture. After that, the mixture is agitated for another $30 \mathrm{~min}$ utes at room temperature before being frozen at -50 ${ }^{\circ} \mathrm{C}$ within 4 hours for gelation. Finally, the sample is freeze-dried under vacuum condition for 48 hours to obtain lightweight FA aerogel. The FA aerogels are fabricated with different FA contents of 3.0, 4.0, and 5.0 wt.\%.

\section{Characterization}

The density of FA aerogels is determined by measuring their weight and volume via diameter and thickness. The porosity $(\varphi)$ of the aerogels is calculated by (Eq. 1) based on their density $\left(\rho_{a}\right)$ and average densities of components $\left(\rho_{b}\right)$.

$$
\begin{gathered}
\varphi=\left(1-\frac{\rho_{a}}{\rho_{b}}\right) \times 100 \\
\rho_{b}=\frac{C_{F A}+C_{C M C}+C_{P V A}}{\frac{C_{F A}}{\rho_{F A}}+\frac{C_{C M C}}{\rho_{C M C}}+\frac{C_{P V A}}{\rho_{P V A}}}
\end{gathered}
$$

where $C_{F A}, C_{P V A}$, and $C_{P V A}$ are the content of FA, PVA, and CMC, respectively. $\rho_{F A}$ that is the density of FA powder after separation is about $2.26 \mathrm{~g} / \mathrm{cm}^{3}$.

Morphology of FA aerogels is characterized by field emission-scanning electron microscopy (FE-SEM) Hitachi S4800. The specimens are coated with a thin layer of Pt to enhance the resolution of the images captured.

The thermal conductivity of the prepared aerogels is measured by TCi C-Therm Thermal Conductivity Analyzer (Fredericton, NB, Canada) with the modified transient plane source method. The average value is obtained after three measurements for each sample at ambient temperature.

The thermal stability of FA aerogels is investigated by thermogravimetric analysis by LabSys Evo TG/DSC 1600 Setaram in air. The samples are heated from room temperature to $800{ }^{\circ} \mathrm{C}$ with the heating rate of $10{ }^{\circ} \mathrm{C} / \mathrm{min}$. The change in weight of specimens following the temperature is recorded.

The compressive strength of the fabricated aerogels is determined by Instron 5500 (Norwood, USA). During the test, the specimens are under a loading rate of $1.0 \mathrm{~mm} / \mathrm{min}$. 

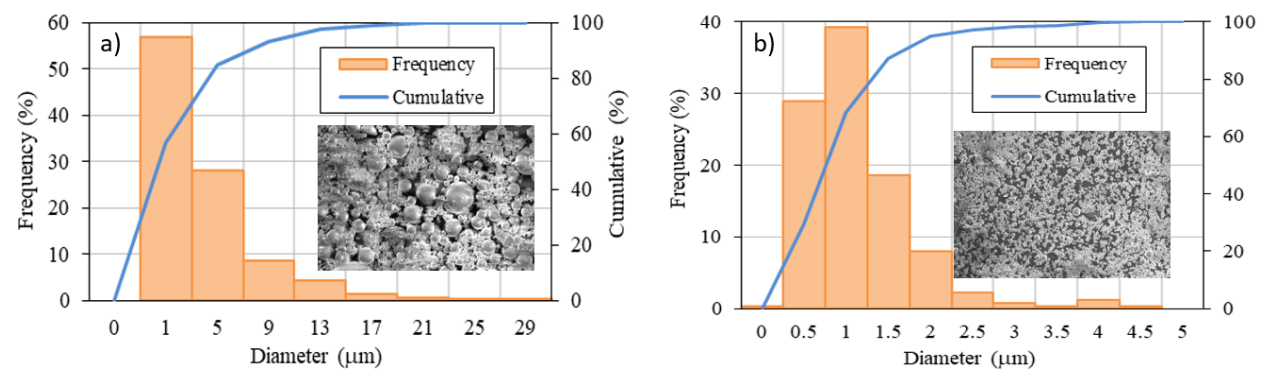

Figure 1: Particle distribution and morphology of FA before (a) and after (b) separation by cyclone system. The SEM images are captured at the same magnification of 1000x.

Table 1: Chemical composition of FA before and after separation

\begin{tabular}{llllll}
\hline Sample & Content (wt.\%) & & & & LOI* $(\%)$ \\
& $\mathrm{SiO}_{2}$ & $\mathrm{Al}_{2} \mathrm{O}_{3}$ & $\mathrm{Fe}_{2} \mathrm{O}_{3}$ & Others & \\
$\mathrm{RFA}$ & 55.07 & 19.10 & 7.25 & 18.58 & 13.0 \\
$\mathrm{SFA}$ & 59.58 & 27.31 & 5.93 & 7.18 & 2.0 \\
\hline
\end{tabular}

${ }^{*}$ LOI: Loss of ignition

\section{RESULTS AND DISCUSSION}

\section{Morphology of FA aerogels}

A combination of FA particles which are separated by cyclone and green binders including PVA and CMC successfully generates FA aerogels (Figure 2a) by ecofriendly and cost-effective freeze-drying method. The sublimation of ice, which is formed at the gelation step, leaves small holes inside the aerogels as can be seen from Figure $2 \mathrm{~b}-\mathrm{d}$. These holes are interconnected and irregular because the freezing process occurs naturally leading to diversity in ice crystal sizes. However, as the network of pores is created, the FA aerogels contain a lot of air making them lightweight with an extremely low density of $0.072-0.093 \mathrm{~g} / \mathrm{cm}^{3}$ as shown in Table 2. Moreover, with increasing FA content, the aerogels become denser because of fewer air pockets and a decrease in pore size. It is predicted that the porosity of FA aerogels also decreases.

Because of the porous network inside, the fabricated aerogels have a high porosity of $94.94-95.78 \%$. As higher FA is used, a decrease in porosity of the aerogel is witnessed because of an increase in the number of particles taking up space inside the aerogel. In contrast, the density of the FA aerogel increases since more and more FA particles are presented in the same unit volume of material. Compared to previous silica aerogels from FA via sol-gel route and ambient drying by Qin et al. $\left(0.0915-0.2379 \mathrm{~g} / \mathrm{cm}^{3}\right)$ and Wu et al. $\left(0.099 \mathrm{~g} / \mathrm{cm}^{3}\right)$, the FA aerogels in this work exhibit much lower density ${ }^{1,8}$. Furthermore, the procedure of synthesizing our FA aerogels uses no alkaline solvents for pretreatment of FA to obtain pure silicate and expensive organic chemicals for surface modification of silica gel before ambient drying as published in previous studies. Hence, the fabrication of FA aerogels saves raw materials cost, is more environmentally friendly and the total synthesis time is reduced $20 \%$ compared to the previous works ${ }^{1,8}$.

\section{Thermal insulation of FA aerogels}

The potential heat insulation of FA aerogels is evaluated by their thermal conductivity which is measured at ambient temperature $\left(25^{\circ} \mathrm{C}\right)$. Overall, the FA aerogels show low thermal conductivity of $0.040-0.047$ $\mathrm{W} / \mathrm{m} . \mathrm{K}$ at $24.1^{\circ} \mathrm{C}$, indicating their excellent heat insulation (Table 3 ). The heat transfer through aerogel is contributed by the conduction of the solid-state network, conduction of gas phase, and radiation within pores $^{9}$. Air is one of the excellent thermal insulators due to its extremely low thermal conductivity of 0.026 $\mathrm{W} / \mathrm{m} . \mathrm{K}^{10}$. Combining the outstanding thermal insulation properties of air and the high porosity of aerogels above $94 \%$, the air captured inside is the main reason why the aerogels have such low thermal conductivity below $0.05 \mathrm{~W} / \mathrm{m} . \mathrm{K}$.

With increasing FA content from 3.0 to $5.0 \mathrm{wt}$ \%, the porosity of FA aerogels decreases causing the efficiency of gas-phase conduction to decrease, and thus, their thermal conductivity increases from 0.040 to 


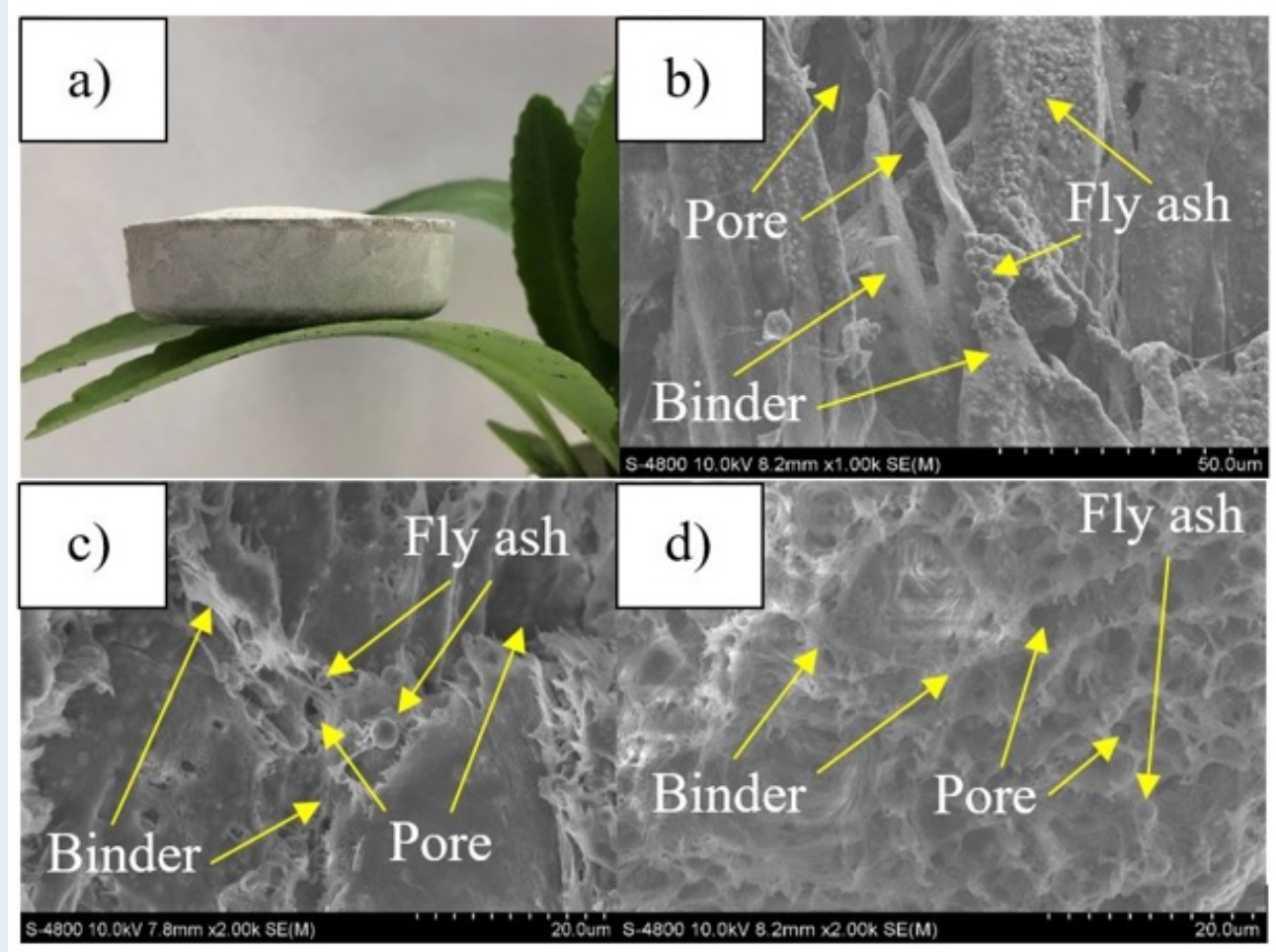

Figure 2: A photograph of ultra-lightweight FA aerogel (a) and SEM images of FA aerogels with different FA contents: (b) $3.0 \mathrm{wt.} \%$, (c) $4.0 \mathrm{wt.} \%$, and (d) $5.0 \mathrm{wt} . \%$.

Table 2: Summary of density and porosity of fabricated FA aerogels

\begin{tabular}{llll}
\hline Sample & FA content $(w t . \%)$ & Density $\left(\mathbf{g} / \mathbf{c m}^{3}\right)$ & Porosity $(\%)$ \\
FAA1 & 3.0 & $0.072 \pm 0.003$ & $95.78 \pm 0.15$ \\
FAA2 & 4.0 & $0.083 \pm 0.002$ & $95.35 \pm 0.12$ \\
FAA3 & 5.0 & $0.093 \pm 0.004$ & $94.94 \pm 0.24$ \\
\hline
\end{tabular}

Table 3: Thermal conductivity and compressive modulus of FA aerogels

\begin{tabular}{lll}
\hline Sample & Thermal conductivity $(\mathbf{W} / \mathbf{m} . K)$ & Young's modulus $(\mathbf{k P a})$ \\
\hline FAA1 & $0.040 \pm 0.001$ & $67.73 \pm 0.14$ \\
FAA2 & $0.044 \pm 0.001$ & $157.63 \pm 0.08$ \\
FAA3 & $0.047 \pm 0.002$ & $254.75 \pm 1.00$ \\
\hline
\end{tabular}

$0.047 \mathrm{~W} / \mathrm{m} . \mathrm{K}$. Moreover, the thermal conductivity of our FA aerogels is comparable to some commercial insulation materials such as mineral wool $(0.030-0.040$ $\mathrm{W} / \mathrm{m} . \mathrm{K})$, fiberglass $(0.033-0.044 \mathrm{~W} / \mathrm{m} . \mathrm{K})$, expanded polystyrene $(0.030-0.040 \mathrm{~W} / \mathrm{m} . \mathrm{K})$ and other silica aerogels from gold mine (above $0.2 \mathrm{~W} / \mathrm{m} . \mathrm{K}$ ), coal gangue $(0.026 \mathrm{~W} / \mathrm{m} . \mathrm{K})$, and dislodged sludge $(0.030$ $-0.087 \mathrm{~W} / \mathrm{m} . \mathrm{K})^{11-14}$. It can be claimed that the aerogels from FA are a promising candidate for practical heat insulation applications.

\section{Thermal stability of FA aerogels}

Regarding the TGA results presented in Figure 3a, a gradual increase in FA concentration plays an impact on the thermal stability of FA aerogels. In the atmospheric condition containing air, the FA aerogels exhibit two main phases of mass change by the temperature as follows: (i) $80-100{ }^{\circ} \mathrm{C}$ and (ii) $250-475$ ${ }^{\circ} \mathrm{C}$. The weight loss of $3-5 \%$ in all samples at the first stage is due to the evaporation of water adsorbed into 
the aerogels because of hydrophilic hydroxyl groups on PVA and CMC matrixes. From 100 to below 250 ${ }^{\circ} \mathrm{C}$, the weight of FA aerogels remains unchanged indicating that the materials can withstand the temperature of up to $250{ }^{\circ} \mathrm{C}$.

However, a significant weight loss of about $40 \%$ is witnessed in the next period as the temperature gradually increases to $475{ }^{\circ} \mathrm{C}$. This thermal decomposition of FA aerogels is because of the degradation of binders including PVA and CMC with the decomposition temperature of 250 and $350{ }^{\circ} \mathrm{C}$, respectively, and the decomposition of $\mathrm{CaCO}_{3}$ and residual coal of original coal in $\mathrm{FA}^{15}$. According to the DTA graph in Figure $3 \mathrm{~b}$, the thermal decomposition of FA aerogels is an exothermic process because the DTA curves have upward peaks, in which the FAA1 gives the highest heat released of nearly $40 \mu \mathrm{V}$ at $430{ }^{\circ} \mathrm{C}$.

At higher temperatures from 500 to $800^{\circ} \mathrm{C}$, the weight of all samples is kept constant since the specimens then consist of only FA and ash resulting from the previous oxidative degradation of PVA and CMC. Although all samples have the same initial decomposition temperature, FAA3 exhibits the highest remaining weight percentage of about $62 \%$ at $500{ }^{\circ} \mathrm{C}$ because its original FA content is the highest among the tested concentrations.
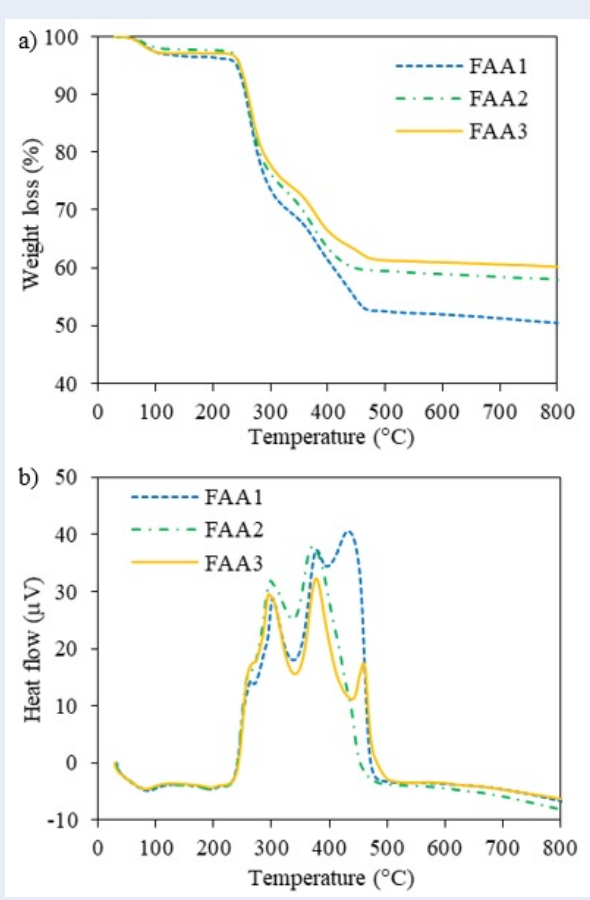

Figure 3: TGA (a) and DTA (b) patterns of FA aerogels at various FA concentrations of 3.0, 4.0, and 5.0 wt.\%.

\section{Mechanical strength of FA aerogels}

The results of the compressive strength of FA aerogels are summarized in Table 2 and Figure 4. As increasing FA content from 3.0 to $5.0 \mathrm{wt}$ \%, Young's modulus of aerogels increases from 67.73 to $254.75 \mathrm{kPa}$, indicating their better durability under loading of 1.000 $\mathrm{N}$ than previous aerogels from wastes such as sugarcane bagasse $(88 \mathrm{kPa})$, pineapple leaf fibers (1.64 $5.34 \mathrm{kPa})$, recycled polyethylene terephthalate (1.16 $2.87 \mathrm{kPa})$, spent coffee grounds $(5.41-15.62 \mathrm{kPa})$, silica - cellulose $(86-169 \mathrm{kPa})^{16-19}$. At the first $10 \%$ of strain known as linear elastic region, the stress increases with increasing FA content, in which that for aerogel composed of $5.0 \mathrm{wt} . \%$ is highest ${ }^{20}$. However, the sample containing $4 \mathrm{wt} . \%$ FA has the same stress at $10 \%$ strain as the one having $5 \mathrm{wt} . \%$ FA. This may be because the porous structure of FAA2 collapses then, causing a considerable increase in the compressive stress.

\section{CONCLUSION}

For the first time, FA has been successfully converted into durable and thermal insulation aerogels by using eco-friendly binders such as polyvinyl alcohol and carboxymethyl cellulose and freeze-drying technique. The fabricated FA aerogels are lightweight with low density and high porosity since the porous structure is formed after sublimation of distilled water without any damage. A special feature of FA aerogels in this work is their outstanding compressibility over previous aerogels which have been synthesized before. Therefore, FA aerogel is demonstrated to be a promising candidate for heat insulation in practice.

\section{ACKNOWLEDGEMENT}

The research is funded by Ho Chi Minh City Foundation for Science and Technology Development, under grant number 120/2019/HĐ-QPTKHCN. We also acknowledge the support of time and facilities from Ho Chi Minh City University of Technology (HCMUT), VNU-HCM, and Institute for Tropicalization and Environment for this study.

\section{ABBREVIATION}

BET: Brunauer-Emmett-Teller

CMC: Carboxymethyl cellulose

DTA: Differential thermal analysis

DW: Distilled water

FA: FA

LOI: Loss of ignition

PVA: Polyvinyl alcohol

RFA: Raw FA 


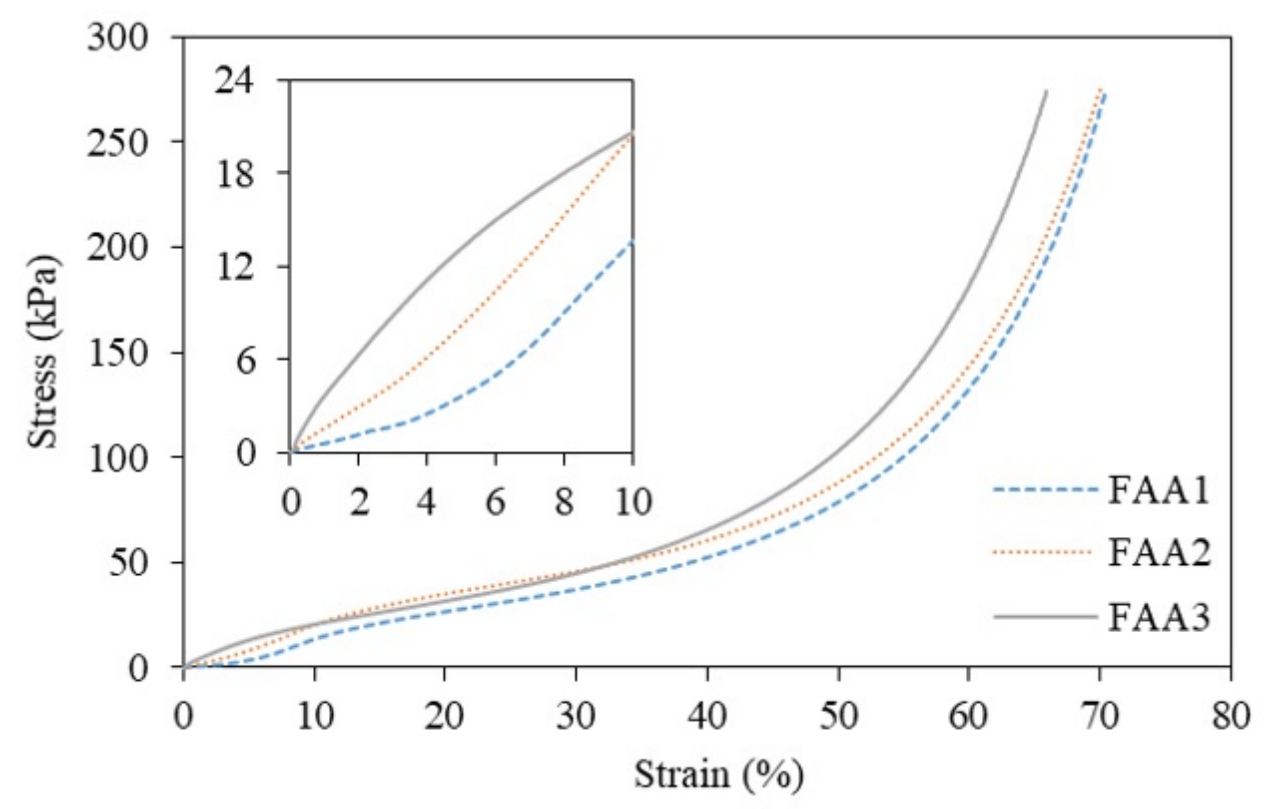

Figure 4: Stress and strain curves of FA aerogels with increasing FA concentration under the loading of 1 kN.

SEM: Scanning electron microscopy

SFA: Separated FA

TGA: Thermogravimetric analysis

TMCS: Trimethylchlorosilane

\section{COMPETING INTERESTS}

The authors declare that they have no competing interests.

\section{AUTHORS' CONTRIBUTIONS}

Nga Hoang Nguyen Do: Conceptualization, Visualization, Writing - original draft. Huy Gia Tran: Methodology, Investigation, Formal analysis. Huong Ly Xuan Doan: Characterization, Data analysis. Nghiep Quoc Pham: Data curation, Resources. Kien Anh Le: Validation, Writing - review \& editing. Phung Kim Le: Writing - review \& editing, Funding acquisition, Project administration.

\section{REFERENCES}

1. Wu X, Fan M, Mclaughlin JF, Shen X, Tan G. A novel low-cost method of silica aerogel fabrication using fly ash and trona ore with ambient pressure drying technique. Powder Technol. 2018;323:310-322. Available from: https://doi.org/10.1016/j. powtec.2017.10.022.

2. Yao Z, Ji XS, Sarker PK, Tang JH, Ge LQ, Xia MS, Xi YQ. A comprehensive review on the applications of coal fly ash. EarthSci Rev. 2015;141:105-121. Available from: https://doi.org/10. 1016/j.earscirev.2014.11.016.
3. Tiwari M, Bajpai S, Dewangan UK, Tamrakar RK. Suitability of leaching test methods for fly ash and slag: A review. J Radiat Res Appl Sci. 2015;8:523-537. Available from: https://doi.org/ 10.1016/j.jrras.2015.06.003.

4. Zaman A, Huang F, Jiang M, Wei W, Zhou Z. Preparation, properties, and applications of natural cellulosic aerogels: A review. Energ Built Environ. 2020;1:60-76. Available from: https: //doi.org/10.1016/j.enbenv.2019.09.002.

5. Gurav J, Jung IK, Park HH, Kang ES, Nadargi DY. Silica aerogel: Synthesis and applications. J Nanomater. 2010;2010:409310. Available from: https://doi.org/10.1155/2010/409310.

6. Nguyen CV, Lambert P, Tran QH. Effect of vietnamese fly ash on selected physical properties, durability and probability of corrosion of steel in concrete. Materials. 2019;12(4):593. PMID: 30781510. Available from: https://doi.org/10.3390/ ma12040593.

7. Shi F, Liu JX, Song K, Wang ZY. Cost-effective synthesis of silica aerogels from fly ash via ambient pressure drying. J Non-Cryst Solid. 2010;365:2241-2246. Available from: https://doi.org/10. 1016/j.jnoncrysol.2010.08.005.

8. Qin $X, X u J$ J, Feng $Y$, Tahmasebi A, Yu J. An experimental study on production of silica aero-gel using fly ash from coalfired power plants. Adv Mat Res. 2014;p. 1010-1012. Available from: https://doi.org/10.4028/www.scientific.net/AMR. 1010-1012.943.

9. Long LY, Weng YX, Wang YZ. Cellulose aerogels: Synthesis, applications, and prospects. Polymers. 2018;10:623. Available from: https://doi.org/10.3390/polym10060623.

10. Do NHN, Luu TP, Thai QB, Le DK, Chau NDQ, Nguyen ST, Le PK, Phan-Thien N, Duong HM. Heat and sound insulation applications of pineapple aerogels from pineapple waste. Mater Chem Phys. 2020;242:122267. Available from: https://doi.org/ 10.1016/j.matchemphys.2019.122267.

11. Illera D, Mesa J, Gomez H, Maury H. Cellulose aerogels for thermal insulation in buildings: Trends and challenges. Coatings. 2018;8:345. Available from: https://doi.org/10.3390/ coatings 8100345 . 
12. Mermer KN, Yilmaz MS, Ozdemir OD, Piskin MB. The synthesis of silica-based aerogel from gold mine waste for thermal insulation. J Therm Anal Calorim. 2017;129(3):1807-1812. Available from: https://doi.org/10.1007/s10973-017-6371-8.

13. Zhu P, Zheng $\mathrm{M}$, Zhao $\mathrm{S}, \mathrm{Wu} \mathrm{J}, \mathrm{Xu} \mathrm{H}$. A novel environmental route to ambient pressure dried thermal insulating silica aerogel via recycled coal gangue. Adv Mater Sci Eng. 2016;2016:9831515. Available from: https://doi.org/10.1155/ 2016/9831515.

14. Zhu L, Wang Y, Cui S, Yang F, Nie Z, Li Q, Wei Q. Preparation of silica aerogels by ambient pressure drying without causing equipment corrosion. Molecules. 2018;23(8):1935. PMID: 30072663. Available from: https://doi.org/10.3390/ molecules23081935.

15. Santos RP, Martins J, Gadelha C, Cavada B, Albertini AV, Arruda $\mathrm{F}$ et al. Coal fly ash ceramics: Preparation, characterization, and use in the hydrolysis of sucrose. Sci World J. 2014;2014:154651. Available from: https://doi.org/10.1155/ 2014/154651.

16. Thai QB, Nguyen ST, Ho DK, Tran TD, Huynh DM, Do NHN, Luu TP, Le PK, Le DK, Phan-Thien N et al. Cellulose-based aerogels from sugarcane bagasse for oil spill-cleaning and heat insula- tion applications. Carbohydr Polym. 2020;228:115365. PMID: 31635729. Available from: https://doi.org/10.1016/j.carbpol. 2019.115365.

17. Koh HW, Le DK, Ng GN, Zhang X, Phan-Thien N, Kureemun $\mathrm{U}$, Duong HM. Advanced recycled polyethylene terephthalate aerogels from plastic waste for acoustic and thermal insulation applications. Gels. 2018;4:43. PMID: 30674819. Available from: https://doi.org/10.3390/gels4020043.

18. Zhang X, Kwek LP, Le DK, Tan MS, Duong HM. Fabrication and properties of hybrid coffee-cellulose aerogels from spent coffee grounds. Polymers. 2019;11(12):1942. PMID: 31779069. Available from: https://doi.org/10.3390/polym11121942.

19. Feng J, Le D, Nguyen ST, Nien VTC, Jewell D, Duong HM. Silica-cellulose hybrid aerogels for thermal and acoustic insulation applications. Colloids Surf A Physicochem Eng Asp. 2016;506:298-305. Available from: https://doi.org/10.1016/j. colsurfa.2016.06.052.

20. Ma H, Zheng $X$, Luo $X$, Yi Y, Yang F. Simulation and analysis of mechanical properties of silica aerogels: From rationalization to prediction. Materials. 2018;11:214. PMID: 29385745. Available from: https://doi.org/10.3390/ma11020214. 


\title{
Tổng hợp aerogel siêu nhẹ từ tro bay định hướng cách nhiệt
}

\author{
Đỗ Nguyễn Hoàng Nga ${ }^{1,2}$, Trần Gia Huy ${ }^{1,2}$, Đoàn Lý Xuân Hương ${ }^{1,2}$, Phạm Quốc Nghiệp ${ }^{3}$, Lê Anh Kiên ${ }^{3}$, \\ Lê Thị Kim Phụng ${ }^{1,2, *}$
}

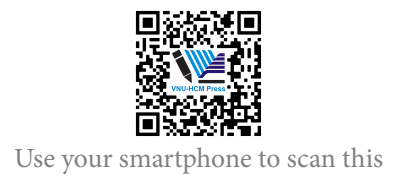

QR code and download this article
${ }^{1}$ Khoa Kỹ thuật Hóa học, Truờng Đại học Bách khoa TP.HCM, 268 Lý Thường Kiệt, Quận 10, Thành phố Hồ Chí Minh, Việt Nam

${ }^{2}$ Đại học Quốc gia Thành phố Hồ Chí Minh, Phương Linh Trung, Quận Thủ Đúc, Thành phố Hố Chí Minh, Việt Nam

${ }^{3}$ Viện Nhiệt đới Môi trường, 57A Trương Quốc Dung, Quận Phú Nhuận, Thành phố Hồ Chí Minh, Việt Nam

\section{Liên hệ}

Lê Thị Kim Phụng, Khoa Kỹ thuật Hóa học, Trường Đại học Bách khoa TP.HCM, 268 Lý Thường Kiệt, Quận 10, Thành phố Hồ Chí Minh, Việt Nam

Đại học Quốc gia Thành phố Hồ Chí Minh, Phường Linh Trung, Quận Thủ Đức, Thành phố Hồ Chí Minh, Việt Nam

Email: phungle@hcmut.edu.vn

Lịch sử

- Ngày nhận: 29-10-2020

- Ngày chấp nhận: 28-12-2020

- Ngày đăng: 13-02-2021

DOI : 10.32508/stdjet.v3i4.786

\section{Check for updates}

Bản quyền

(c) ĐHQG Tp.HCM. Đây là bài báo công bố mở được phát hành theo các điều khoản của the Creative Commons Attribution 4.0 International license.

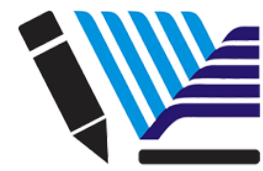

VNU-HCM Press

\section{TÓM TẮT}

Lần đầu tiên một quy trình thân thiện môi trường và hiệu quả để tổng hợp aerogel có giá trị kỹ thuật cao từ tro bay (FA) được xây dựng hoàn chỉnh bằng cách phân tán các hạt FA vào hỗn hợp chất kết dính polyvinyl alcohol (PVA) và carboxymethyl cellulose (CMC) có khả năng phân hủy sinh học và phương pháp sấy thăng hoa. Ảnh hưởng của hàm lượng FA đến các tính chất vật lý, hình thái học, độ bển cơ học và độ dẫn nhiệt của FA aerogel cũng được nghiên cứu. Vật liệu FA aerogel siêu nhẹ được tổng hợp có khối lượng riêng thấp $\left(0,072-0,093 \mathrm{~g} / \mathrm{cm}^{3}\right)$ với độ xốp lớn $(94,94$ 95,78\%). Hình thái học của FA aerogel thể hiện sự phân bố đồng đều của các hạt tro bay trong mạng lưới liên kết giữa PVA và CMC hình thành nên cấu trúc rỗng xốp với kích thước lỗ rỗng là 2-5 mm. Vi vậy, FA aerogel có tính chất cách nhiệt tốt với độ dẫn nhiệt rất thấp $(0,040-0,047 \mathrm{~W} / \mathrm{m} \cdot \mathrm{K})$ ở nhiệt độ phòng và áp suất thường. Bên cạnh đó, độ dẫn nhiệt của tro bay aerogel tương đương với các vật liệu cách nhiệt thương mại như bông khoáng, bông thủy tinh, polystyrene và các loại silica aerogel khác từ chất thải. Thêm vào đó, mô-đun nén của tro bay aerogel từ $67,73-254,75$ $\mathrm{kPa}$, chứng tỏ đặc tính cơ học nổi trội của vật liệu dưới lực nén 1 kN theo phương thẳng đứng. Kết quả thí nghiệm cho thấy độ bền cơ học của tro bay aerogel cao hơn so với các aerogel từ chất thải khác như bã mĩa (88 kPa), sợi lá dứa (1,64 - 5,34 kPa), sợi polyethylene terephthalate tái chế (1,16 - 2,87 kPa), bã cà phê (5,41 - 15,62 kPa), silica - cellulose (86 - $169 \mathrm{kPa})$. Như vậy, FA aerogel là vật liệu cách nhiệt siêu nhẹ đầy tiềm năng.

Từ khoá: Tro bay, Aerogel, Cách nhiệt, Hình thái học, Độ bền cơ học
Trích dẫn bài báo này: Nga $D N H$, Huy $T$ G, Hương $D L X$, Nghiệp $P Q$, Kiên L A, Phụng L T K. Tổng hợp aerogel siêu nhẹ từ tro bay định hướng cách nhiệt. Sci. Tech. Dev. J. - Eng. Tech.; 4(1):637-644. 